\title{
Agritourism activities in the Mopani District Municipality, Limpopo Province, South Africa: perceptions and opportunities
}

\author{
SL MYER ${ }^{1}$ AND EP DE CROM
}

\begin{abstract}
Farms in South Africa have to compete in a very hostile agricultural economic environment and it has become imperative for farmers to find new ways of generating additional income. Research undertaken in the Mopani District Municipality (MDM) in the Limpopo Province of South Africa identified agritourism as a potential means to this end. The main aim of this primarily qualitative study was to gain a better understanding of the perceptions and opportunities for agritourism in the study area. Data were mainly collected through interviews and questionnaires. Participants consisted of farmers and tourists, as well as owners of existing agritourism farms within the MDM. Five current active agritourism establishments were identified. Key findings revealed that agritourism is not being utilised to its full potential. Although perceptions of respondents towards agritourism are positive, marketing around it is insufficient and not all farmers are willing to host agritourism activities on their farms for various reasons. However, the MDM is a tourist hub with many visitors passing through the area en route to the Kruger National Park. Therefore, the potential already exists to host agritourism activities that will benefit farmers in various ways. By developing farm trails, scheduling daily farm activities, using information brochures, forming networks with existing tourist establishments, encouraging the use of local and fresh produce and providing good roadside signage, farmers can gain increased exposure and recognition for what they do and opportunities for growth and development may be realised.
\end{abstract}

Keywords: Agritourism, farm tourism, alternative tourism, farm activities, tourism

\section{Introduction}

Poor agriculture commodity prices, rising production costs, globalisation, industrialisation, the encroachment of suburban development, loss of government-supported agricultural programs and the elasticity of commodity markets, have led farm families to explore the viability of alternative economic strategies in an effort to preserve the family farm (Weaver \& Fennell, 1997, Lobo et al., 1999 and Doyle \& McGehee, 2002). One of the driving forces among agricultural sectors to diversify their income sources is to embrace tourism practices

1. SL Myer, Tshwane University of Technology, Department of Nature Conservation, Private, Bag X680, Pretoria, 0001. Email: stephanie.myer@gmail.com.

2. Corresponding author: EP de Crom, Tshwane University of Technology, Department of Nature Conservation, Private Bag X680, Pretoria, 0001. Email: decromep@tut.ac.za 
into their daily farming activities (Viljoen \& Tlabela, 2006:15). This is known as agritourism and it may be regarded as an alternative form of tourism that falls under nature tourism.

Agritourism can be defined as the act of visiting a working farm, or agribusiness enterprise, for the purpose of enjoyment, education or active involvement in the activities of the farm or operation (Che, Veeck \& Veeck, 2005:227). The inception of agritourism into traditional farming practices is a relatively new concept in South Africa and is based on the premise of attracting visitors to farms.

However, according to the White Paper on the Development and Promotion of Tourism (SA, 1996:6), tourism has been inadequately resourced and funded. There is little integration of local communities and previously neglected groups into tourism. Tourism education and training are lacking and there is inadequate protection of natural environments. Poor service delivery and lack of infrastructure (particularly in rural areas) are also outlined. The growing levels of crime and violence on visitors remain an on-going problem. This has led the researcher to believe that not enough has been done to promote agritourism to its full potential in South Africa and specifically in the study area.

While there are a number of constraints associated with tourism development in South Africa, many opportunities and benefits exist for agritourism. Agritourism has been identified as a unique opportunity for the Mopani District Municipality (MDM) to combine its diverse agricultural industries with tourism. According to Pittman (2006), agritourism provides a number of financial, educational and social benefits to tourists, producers and communities and these include:

- providing producers with the opportunity to generate additional income through tours, accommodation or selling directly to the consumer;

- stimulating economic development in the form of additional employment opportunities;

- providing the public, particularly children, with the opportunity to learn about agriculture and food production;

- providing an alternative use for agricultural land that can help maintain the viability of the operation;

- providing communities with opportunities to develop business enterprises;

- providing visitors with an alternative form of tourism;

- providing local tourism officials with the opportunity to enhance existing tourism attractions; and

- helping to achieve the tourism goal of increasing the volume of visitors to the specific area.

Agritourism is a relatively recent phenomenon in South Africa that is not being utilised to its full potential. There is a lack of tourism awareness at a national, provincial and local level (SA, 1996:6). This leads to the question of whether enough is being done to promote guest farms or agritourism in South Africa. It further prompts the question of whether tourists (general public) are aware of agritourism establishments and their potential in South Africa in general and for this study, specifically in and around the MDM of the country.

The area chosen for this study is confined to current and potential agritourism establishments in the MDM. The MDM lies in the Limpopo Province of South Africa, in the northernmost reaches of the country where it shares its borders with Botswana in the west, Mozambique in 
the east and Zimbabwe in the north. The MDM has the potential of becoming an excellent ecotourist destination area as its eastern border lies next to the Kruger National Park (KNP) (Blunt, 2009:32). The KNP is a world-renowned wildlife sanctuary for large game and attracts many visitors to the area. Agriculture plays a significant role with regards to employment and subsequently, the economy, in the MDM. Approximately 50\% of the farming income earned in Limpopo is derived from horticultural farming activities centered in the MDM with subtropical fruits, citrus and vegetable farming making up the remainder of it (Blunt, 2009:33).

\section{Methods}

The nature of this study is primarily qualitative with aspects of quantitative methods incorporated during data gathering, analyses and interpretation.

Required data was collected from fresh produce farmers within the boundaries of the MDM, local tourists (i.e. residing in South Africa) that were visiting the region or passing through the area to other destinations, and co-workers of the researcher who were approached according to their knowledge of the industry as they work closely with the farm owners in the study area. Non-probability sampling techniques were used, namely purposive, convenience and snowball sampling. The sample size was based on information need; hence, the guiding principle in sampling was data saturation (Guest, Bunce \& Johnson, 2006). Thus, all the participants were sampled to the point at which no new information was obtained and saturation was achieved.

Primary data were collected using interviews and questionnaires over three years (2009-2011) during weekends and holiday periods and during times of festivals and other arranged farm activities. Open content analysis and descriptive statistics were used to describe the information collected from the interviews and questionnaires.

\section{Results and Discussion}

This study was based on the following objectives:

- to investigate what agritourism opportunities exist in the Mopani District Municipality of South Africa;

- to determine what the perceptions of visitors and farm owners are with regards to agritourism in the study area;

- to determine what the preferences of visitors are when visiting agritourism establishments in the study area;

- to determine the benefits of incorporating agritourism activities into classical farming practices; and

- to provide recommendations to developing agritourism in the study area.

\subsection{Current agritourism opportunities}

Current agritourism establishments incorporated in this study and regarded as having potential to further promote active agritourism in the area are located in Magoebaskloof and 
Tzaneen. They include The Wegraakbosch Organic Dairy Farm, Kuhestan Farm, Thomac Oil Distillery and The Coach House. ZZ2 Boerdery, located near Modjajiskloof, was also included in the study area.

These establishments have been identified by the researcher as being strategically placed in promoting agritourism in the area, especially because they are known establishments that frequently appear in the local tourism brochure. Two of them, being the Coach House and Kuhestan Farm, have established websites that potential visitors can access. In addition, these two farms have taken the initiative by allowing visitors to participate in day tours, or to spend the night to 'imbibe' the atmosphere which these kinds of destinations have to offer. Further development of this agritourism initiative could be more readily realised in the future if a synergism was developed between the local communities and other farm owners in the area.

\subsection{Perceptions of respondents}

Results revealed that $58 \%$ of all the respondents have heard of agritourism. In a study done to determine the potential for agritourism development in Sri Lanka, Malkanthi and Routry (2011) found that one of the drawbacks for effective implementation was that although farmers were found to be knowledgeable about their farming activities, they failed in awareness of the potential of agritourism to stimulate the local economy. The relatively high number of people in the MDM who are not aware of agritourism (42\%) may thus be ascribed to ineffective or non-existent marketing of the concept, as well as overlooking its potential as a source of income to the area. This notion was borne out by respondents in this study, who confirmed that the marketing effectiveness of agritourism in South Africa is poor.

An attempt was made to establish the extent of the tourists' awareness/exposure to the agritourism concept, as well as their relative perceptions thereof. It was determined that $95 \%$ of the tourists were of the opinion that South Africa needs agritourism. Reasons given were that agritourism provides a platform to educate tourists and/or members of the general public, who are subsequently provided with the opportunity to learn more about agriculture and food production, a finding supported by Pittman (2006). According to Raghunandan, Horner and Schuepbach (2010), there is a definite lack of awareness amongst children regarding human dependence on the environment, including the efforts that farmers expend in food production. Through agritourism, greater awareness of food production and the importance of food security to a nation may help people to better understand the contribution that agriculturalists make to society.

Whereas some parts of South Africa are better advertised than others, it is often left to the farmers themselves to manage all the marketing and compiling of promotional material. According to Williams et al. (2001:98), some of the critical issues facing the agritourism industry, such as the establishment of marketing partnerships, are limited to the use of available channels of distribution.

Since farming contributes very little to the South African Gross Domestic Product (GDP) (Mather \& Adelzadeh, 1997; Department of Agriculture, Forestry and Fisheries, 2010), incorporating agritourism activities into traditional farming practices may help boost the economy. A number of studies done on agritourism have shown that farmers in dire straits facing decreased profits and difficulties within the agricultural industry can embrace agritourism as an alternative source of income (Oredegbe \& Fadeyibi, 2009:9). Diversification along these lines can thus be viewed as a means of survival for farm businesses, with tourism becoming an attractive and feasible funding stream. Farmers can also benefit 
from the increased exposure that agritourism creates for them. For example, a local farmer in the study area commented that even though they are trying to promote themselves on a private basis, agritourism could help them reach a greater audience. He said: "We are trying to promote as much as we can on a private basis but it could be streamlined and it could be widened to cover the area, the product and the facilities we offer" (Respondent 10, 2011).

On the question of whether tourists regard South Africa as an attractive agritourism destination, the majority of respondents (89\%) agreed that South Africa is indeed an attractive agritourism destination. South Africa is considered to be one of the most diverse and enchanting destinations in the world (SA-venues, S.a.). As a whole, the country boasts a combination of unrivalled landscapes, friendly people, diverse history and culture that inspires a unique experience for any visitor. South Africa is seen as having a diverse range of tourist activities coupled to special interest attractions, such as that of wine tourism (World Travel and Tourism Council, 2002). By way of example, the SA wine industry, according to Hands and Hughes (1997) and Bruwer (2003), is one of the oldest industries outside Europe, dating back to the mid-seventeenth century. According to studies conducted by the City of Cape Town (2002), as well as by Grant Thornton Kessel Feinstein (2002) and the World Travel and Tourism Council (2002), visitation of wine routes by international and domestic tourists was ranked as the fourth most popular attraction in South Africa.

Respondents in the $11 \%$ category (who felt that South Africa is not an attractive agritourism destination) cited crime and political instability in South Africa as being a major factor in making the country unattractive for tourism in general. Evidence gathered in many parts of the world has demonstrated that safety, as well as peace and tranquillity are necessary for any tourism industry to prosper (Sonmez \& Graefe, 1998; Pizam \& Mansfield, 2006). According to the SA Tourism Brand Tracker, in January 2005, 22-25 million potential travellers, across eight key markets (United States of America, United Kingdom, Germany, France, the Netherlands, Australia, India and China), did not consider South Africa as a suitable travel destination because of safety concerns (Department of Environmental Affairs and Tourism, 2005:29). However, respondents in this study listed many reasons why South Africa could indeed be considered an attractive destination for agritourism visitors. They maintained that South Africa is rich in resources with an abundance of good soil types, clean air and water, all of which supports a large diversity of farming activities and products. Some specifically mention that our SA environment and weather is conducive for diverse farming, allowing for a wide variety of products to be placed in the market place. These findings correspond with a study done by Williams et al. (2001), which found factors that determine why visitors travel, include favourable weather, outstanding scenery, as well as a variety of things to see and do, all of which adds up to greater appreciation by the tourists for knowledge thus gained.

Another attractive feature of South Africa is its people. In New Zealand, country friendliness has extended into a commercial product (Pearce, 1990:347). Much of the success of New Zealand farm tourism depends on the perceived friendliness of the hosts. Many of South Africa's small-scale farms are organic and labour intensive. According to a respondent, overseas visitors like to visit South Africa's farms because "they are like how our farms used to $b e$ " when machinery featured less. She added that visitors "experience an authentic farm atmosphere when visiting South African farms" (Respondent 4, 2011). In a study done by Cohen (2002), tourists are frustrated with 'staged authenticity' of tourist settings, preferring real authenticity of the site or at least to have an authentic farm experience. 
Even though there are a number of factors that make South Africa, and especially the study area, a worthwhile agritourism destination, some of the challenges that the local farms may face, is one of accessibility. Tourists are of the opinion that getting to some of the farms in the wet weather may prove quite challenging without a 4-wheel drive vehicle, because of poor road conditions. In addition, many of the farms are too far away from urban areas to visit in one day. A third of the respondents however, were of the opinion that travelling on gravel roads leading to the farms contributed to the farm visit experience. The infrastructure that is able to host agritourism activities on the farms already exists. In addition, there are a total of 660 beds in Bed \& Breakfast establishements and hotels in the area, as well as some good camping sites and many restaurants. The roads leading to the farms are well sign-posted and well maintained for the sake of being able to transport goods (Respondent 3, $6 \& 7,2011$ ).

Despite some negativity, it can be concluded that the overall perceptions of the majority of respondents towards the promotion of agritourism in the study area, were positive.

\subsection{Preferences of tourists to agritourism establishments}

Results show that there exists a positive attitude among visitors within the study area with regards to participation in agritourism activities, where $84 \%$ of the tourist responses indicated positive participation in agritourism-related activities. Only a small percentage (4\%) was not interested in agritourism activities, while another $12 \%$ were unsure.

Reasons that visitors gave for being interested in participating in agritourism activities were primarily related to the enhancement of knowledge. Respondents were of the opinion that people are not fully informed about where their food comes from, or how it is produced. It would appear that there is an underlying motivation to meet the producers and talk to them about what goes into food production. Children who visit the farms have often not seen a live duck or pig and in many cases not picked an apple right off the tree (Miller, Vandome \& McBrewster, 2010:2). Agritourism can thus be considered an alternative form of tourism which even children can enjoy and participate in.

However, as indicated by the visitors, their extent of participation would be to only visit a farm for the sake of their children and only if it was en-route to their destination. For most people farm activities are not nearly as appealing as a more passive involvement (Hood, 1995). Only the younger generations appear interested in active participation via farm chores. Would-be visitors in this category are considerably more enthusiastic about watching a demonstration, or being entertained, and leap at the chance of churning butter or pitching hay on a farm. However, persons such as executives, professionals and managers appear to be especially disenchanted by these kinds of options (Hood, 1995).

Visitors in this study who indicated that they would observe an agritourism activity, but with limited participation, maintained a participative interest in a farm tour or fruit festival, where the fruits could subsequently be tasted.

\subsection{Benefits of hosting agritourism activities on farms}

Tourists to the study area were asked to indicate what they think could be possible benefits to farmers from hosting agritourism activities on their farms. These benefits are illustrated in Table 1. 
TABLE 1: Possible benefits of agritourism activities on farms as seen by tourists $(n=77)$

\begin{tabular}{|l|l|}
\hline Education of tourists & $56 \%$ \\
\hline Exposure & $27 \%$ \\
\hline Income for farmers & $17 \%$ \\
\hline Local tourist interest & $15 \%$ \\
\hline Value-added products & $9 \%$ \\
\hline Recognition for farmers & $8 \%$ \\
\hline
\end{tabular}

One of the most important benefits mentioned is that tourists are being educated in local food production (56\%). Linked to this, agritourism then creates increased exposure to farmers (27\%), who would also be able to increase their income by selling products directly to the consumer, without incurring extra costs on a middleman (17\%).

Studies done on consumers' attitudes have shown that buyers are increasingly demanding better quality of fresh fruits and vegetables and that they are willing to pay premium prices for it (Connel, Beierlein \& Vroomen, 1986; Eastwood, Orr \& Brookers, 1986; Rhodus, Schwartz \& Hoskins, 1994). The growing awareness of consumers relating to the health of synthetic agricultural inputs has created a demand for more specialised produce (Govindasamy, Italia \& Liptak, 1997).

Farmers are increasingly supplying more organically produced products, such as Integrated Pest Management (IPM) and naturally ripened produce. In addition, farmers are providing various value-added farm products, such as homemade jams, pies, bread and even flower bouquets through direct markets (Nayga et al., 1994). By adding value to their products, farmers in the MDM have the opportunity to earn extra income by setting up a certain measure of catering, to address some of the needs of the consumers in this particular setting.

Farmers can also supplement their income from the hosting of tours on their farms. Farmers in the northeastern states of America have diversified their farm operations into several new directions such as providing farm tours, hayrides, festivals, petting zoos, and on-farm picnic facilities (Govindasamy et al., 1997). These activities provide people, especially children, an opportunity for experiencing an introduction to farm life in a novel manner, but also succeed in offering the urban communities a retreat from the congestion of the cities (Adelaja, 1995). These activities mainly utilise existing farm resources, offering the farmers the potential to substantially increase their farm income without any additional costs, simultaneously educating the visitor and gaining increased exposure for themselves.

A further benefit of agritourism activities on farms identified by tourists is the fact that local tourist interest is on the increase, as more and more people are seeking new and out-of- theordinary things to experience. The following comment serves as an example of this opinion: 
Tourists like to see how people do things in South Africa. When they come to a farm, they like to see the workers and have some sort of personal communication with the staff. They like to see crops being planted. This is a labour intensive organic farm and overseas everything would be done by machinery. This is like how farms used to be (Respondent 4,2011).

Tourists also like to have a look at how a farm is run, how the fruits are picked, how it is packed, how the packing house works and how do they get the fruits to the market. In addition, they have the opportunity to buy fresh produce at an affordable rate (Vaupel, 1985).

According to $9 \%$ of the respondents (Table 1), small scale farmers are also able to generate more income from value-added products. Although farmers have much to gain from incorporating agritourism activities into their traditional farming practices, this study shows that there is a tendency of scepticism among the farmers to host such activities. Only about half of the respondent farmers (49\%) indicated that they were willing to host agritourism activities on their farms. The main reason provided was the fact that they did not have the time for it. Colton and Bissix (2005) substantiate this by saying that this constraint may be traced back to the inability of the government to reach farmers and encourage them to diversify.

Farmers are also afraid that visitors might damage their crops, for example, by breaking the growth tip of the branch, which sets the whole balance back by one year. The Washington State Department of Agriculture (2010:2) verifies this by saying that some of the challenges that the farmers face when allowing visitors onto their farms, are that their liability insurance becomes more costly. Visitors may cause damage to the crops or lose some of the products in the fields.

Furthermore, day visitors may disrupt normal farming activities. According to Williams et al. (2001), agritourism can create benefits for farm and tourism operators, but it can also increase the chances of conflict between primary farming pursuits and more leisure travel activities. These conflicts may relate to issues of noise, smell, farming practices and disease control. Farmers may also feel that agritourism weakens their identities (Brandth \& Haugen, 2010:8). They place emphasis on how well the farm is managed, how the fields are ploughed, how evenly the fertilizer has been distributed and even how large the crops are. This is what governs their impression of a farmer, gives status and confirms identity in relation to other farmers (Brandth \& Haugen, 2010:3). When they incorporate agritourism into their farming practices, the importance is then shifted to the audience, namely the visitors.

Even though the majority of the farmers are unwilling to take advantage of the agritourism opportunities in a particular area, the potential remains undiminished, as demonstrated by the $49 \%$ of the farmers who were willing to host agritourism activities on their farms.

\section{Conclusion and Recommendations}

The concept of agritourism as an industry is not established in South Africa and needs to be further developed (Tifflin, 2005).

A model that the local municipalities can use to develop agritourism in the MDM is to nurture subsistence farmers into small-scale farmers. According to Scialabba (2000:10), subsistence farmers represent a large part of the farming community in the developing world. Farms in developing countries produce for consumption, but should be encouraged to farm 
for greater income sources, conservation of natural resources, food self-reliance and rural development (Scialabba, 2000:3).

A further suggestion is that the farming community and local authorities in the MDM should work together to develop 'farmer markets'. A growing section of consumers wish to buy local produce, with an increasing preference for organic commodities (Das \& Rainey, 2010:278). Farmer markets provide exposure for farmers and draw visitors to the specific area. For the consumer, farmer markets provide affordable products, as there is no middleman, market fees, agent fees and huge transport expenses. Visitors (consumers) can also assist the farming community through supplementary income.

The following activities and attractions, adapted from Denman and Denman (1993), may also be incorporated on farms intended for agritourism development in the MDM:

- Develop farm trails. A good example of this is the Stellenbosch Wine Route in the Western Cape. It was first established in April 1971 by the owners of three wineries who set about encouraging producers to bottle their own wine and to introduce the public to their wine estates (Nowers, de Villiers \& Myburgh, 2002). Eleven wine producers were eventually incorporated as the first members of this route. Its success led to the establishment of various other wine routes in the area where local wine producers could encourage direct and indirect wine sales on their farms, coordinate collaborative promotion of their members' products and stimulate generic brand advertising. Farmers in the MDM can link up with neighbouring farms in the area and collaborate on creating and running a farm route or trail that will promote regional tourism in the area.

- Incorporate wildlife and conservation interests in farm tours. Farmers are knowledgeable about their farms; they are familiar with the surrounding landscape and the natural environment, making them legitimate experts in the field. Owing to the presence of many other tourism destinations in the MDM (ecotourism, culture tourism and adventure tourism), farm owners can benefit by having close relationships with them, generating new sources of income through horizontal linkages with other tourism based activities. Farm owners can provide tour packages from their farms to nearby attractions.

- Provide background information on farm for guests in the form of hand-outs. These hand-outs may provide information on the history of the farm and any other information that explains what the farm does and how it operates.

- Emphasise the use of local produce. By buying local produce, more money is injected into the local economy. Farmers can benefit from direct sales when visitors purchase directly from them when the visitors participate in a farm tour or stay.

- Provide good roadside signage along with clear directions which can draw the attention of potential visitors to previously isolated farms that may have been missed en route to their destination.

- Schedule daily farm activities in which guests can participate.

- Consideration should be given to a farm tourism brochure directing guests to various farm related attractions. For example, the Stellenbosch Wine Route in the Western Cape mentioned earlier. Should similar tourism brochures be available in the MDM, these brochures could be distributed to various tourism information offices elsewhere in the country. This will not only advertise the region, but also introduce additional tourism attractions in the area already known for its natural scenery and wildlife. 
- Maintain strong links with other B\&B establishments. Small agritourism producers can cooperate with other tourism enterprises and learn from other entrepreneur's experiences through information sharing. By referring customers to other businesses (if unable to accommodate customers themselves) builds service-derived goodwill among individual businesses and ultimately satisfies the customers. Producers should not view other agritourism operators as their competitors but rather compete with supermarkets and other entertainment outlets that take customers' food and leisure activities away from them.

Farmers can also make use of new marketing and communication channels such as brochures and web linkages that provide consumers with information on previously isolated agritourism providers. They can form marketing alliances to share resources relating to advertising, promotion and marketing information. The benefit of this is that it may also lead to information sharing. A cooperative approach strengthens an area's agritourism reputation more than what a competitive approach would do.

By combining tourism with the uniqueness and diversity of local agriculture, agritourism may generate diversification opportunities for local farmers to increase their revenue and enhance the viability of their operations. Agritourism may be an excellent tool to educate the public about the importance of agriculture and its contribution to the country's economy and quality of life. It may provide economic incentives and reduce friction in the agricultural-urban interface, thus helping to preserve agricultural land in the MDM. Agritourism may enhance the appeal and demand for local products, foster regional marketing efforts and create valueadded and direct marketing opportunities that may stimulate economic activity and spread the benefits to various other communities in the country.

It would clearly be to the advantage of the local municipalities and government agencies to devote more resources to promoting agritourism. The research and observation conducted within the study area leads to the conclusion that both local communities and farmers stand to benefit a great deal if the valuable resource that is agritourism were to be exploited to its full potential.

\section{Acknowledgements}

The authors would like to thank Tshwane University of Technology and the NRF for their financial support.

\section{References}

PRIMARY RESOURCES (Original notes and transcripts in the personal archive of the head author)

RESPONDENT 3. 2011. Interview. Haenertsburg, Limpopo Province. 
RESPONDENT 4. 2011. Interview. Magoebaskloof, Limpopo Province.

RESPONDENT 6. 2011. Interview. Magoebaskloof, Limpopo Province.

RESPONDENT 7. 2011. Interview. Tzaneen, Limpopo Province.

RESPONDENT 10. 2011. Interview. Magoebaskloof, Limpopo Province.

\section{SECONDARY RESOURCES}

ADELAJA, A. 1995. Enhancing the viability of New Jersey's farms through farm based recreation and tourism. (Paper presented at the Workshop on Skylands Rural and Recreational Tourism, June 2, Phillipsburg, New Jersey). Unpublished.

BLUNT, W. 2009. Limpopo: Mining and Industries. Polokwane: Emerging Publications.

BRANDTH, B. \& HAUGEN, M.S. 2010. Farm diversification into tourism: Implications for social identity? Journal of Rural Studies, 30:1-10.

BRUWER, J. 2003. South African wine routes: some perspectives on wine tourism industry's structural dimensions and wine tourism product. Tourism Management, 24:423-425.

CHE, D., VEECK, A. \& VEECK, G. 2005. Sustaining production and strengthening the agritourism product: linkages among Michigan agritourism destinations. Agricultural and Human Values, 22:225-234.

CITY OF CAPE TOWN. 2002. Cape Town Tourism Development Framework: Market Assessment. April. City of Cape Town.

COHEN, E. 2002. Authenticity, equity and sustainability in tourism. Journal of Sustainable Tourism, 10(4):267-276.

COLTON, J.W. \& BISSIX, G. 2005. Developing agritourism in Nova Scotia: issues and challenges. Journal of Sustainable Agriculture, 27(1):91-112.

CONNELL, C.M., BEIERLEIN, J.G. \& VROOMEN, H.L. 1986. Consumer preferences and attitudes regarding fruit and vegetable purchases from direct market outlets. Department of Agricultural Economics and Rural Sociology Bulletin, 185, May: $1-83$.

DAS, B.R. \& RAINEY, D.V. 2010. Agritourism in the Arkansas delta byways: assessing the economic impacts. International Journal of Tourism Research, 12:265-280.

DEMOMBYNES, G.I. \& BERK, O. 2005. Crime and local inequality in South Africa. Pretoria: HSRC Press.

DENMAN, R. \& DENMAN, J. 1993. The farm tourism market: a market study of farm tourism in England. Herefordshire, UK: The Tourism Company.

DEPARTMENT of Agriculture, Forestry and Fisheries see SOUTH AFRICA. Department of Agriculture, Forestry and Fisheries.

DEPARTMENT of Environmental Affairs and Tourism (DEAT) see SOUTH AFRICA. Department of Environmental Affairs and Tourism. 
DOYLE, A.B. \& MCGEHEE, N.G. 2002. Case statement for the development of agritourism in the Commonwealth of Virginia. Unpublished document. Blacksburg, VA: Virginia Tech.

EASTWOOD, D., ORR, R. \& BROOKERS, J. 1986. Consumer stated preferences for selected fresh produce and vegetables. University of Tennessee Agricultural Experiment Station. University of Tennessee, Research Report, 86-06.

GOVINDASAMY, R., ITALIA, J. \& LIPTAK, C. 1997. Quality of agricultural produce: consumer preferences and perceptions. New Jersery Agricultural Experiment Station. Rutgers University, Research Report P-02137-1-97.

GRANT THORNTON KESSEL FEINSTEIN. 2002. Western Cape Tourism Trends. Cape Town: Western Cape Tourism Board.

GUEST, G., BUNCE, A. \& JOHNSON, L. 2006. How many interviews are enough? An experiment with data saturation and variability. Field Methods, 18(1):59-82.

HANDS, P. \& HUGHES, D. 1997. Wines and brandies of the Cape of Good Hope: The definitive guide of the South African wine industry. Somerset West: Stephen Collins.

HOOD, M.G. 1995. A view from 'outside': research on community audiences. Visitor Studies, 7(1):77-87.

LOBO, R.E., GOLDMAN, G.E., JOLLY, D.A., WALLACE, B.D., SCHRADER, W.L. \& PARKER, S.A. 1999. Agricultural tourism: agritourism benefits agriculture in San Diego County. UC Small Farm Program. California Agriculture, Nov.-Dec.

MALKANTHI, S.H.P. \& ROUTRY, J.K. 2009. Potential for agritourism development: evidence from Sri Lanka. Journal of Agricultural Sciences, 6, Jan.:45-58.

MATHER, C. \& ADELZADEH, A. 1997. Macroeconomic strategies, agriculture and rural poverty in post-war apartheid South Africa [Online]. Available from: www.info.gov.za [Accessed: 15/03/2012].

MATZARAKIS, A., DE FREITAS, C. \& SCOTT, D. 2004. Advances in tourism climatology. Freiburg: Berichte des Meteorologischen Institutes der Universität.

MILlER, F.P., VANDOME, A.F. \& MCBREWSTER, J. 2010. Agritourism. Mauritius: Alphascript.

NAYGA, R., FABIAN, M.S., THATCH, D.W. \&WANZALA, M.N. 1994. Farmer-toconsumer direct marketing: characteristics of New Jersey Operations. New Jersey Agricultural Experiment Station Publication, March, No. P-02453-1-94, Rutgers University.

NOWERS, R., DE VILLIERS, E. \& MYBURGH, A. 2002. Agricultural theme routes as a diversification strategy: the Western Cape wine routes case study. Agrekon: Agricultural Economics Research, Policy and Practice in Southern Africa, 41(2):195-209.

OREDEGBE, A. \& FADEYIBI, I. 2009. Diversification into farm tourism. (Paper presented at the International Conference on Regional and Urban Modelling, June, University of Ottawa, Ontario) [Online]. Available from: http://ecomod.net/sites/default/files/document-conference/ecomod2009/859.pdf [Accessed: 2011/06/30]. 
PEARCE, P.L. 1990. Farm tourism in New Zealand: a social situation analysis. Annals of Tourism Research, 17:337-352.

PITTMAN, H.M. 2006. Planting the seeds for a new industry in Arkansas: agritourism. $A$ National AgLaw Center Research Publication, Aug.:8-9.

PIZAM, A. \& MANSFIELD, Y. 2006. Tourism, crime and international security issues. New York: John Wiley \& Sons.

RAGHUNANDAN, A., HORNER, S. \& SCHUEPBACH, E. 2010. Agritourism in India: the potential for sustainable development and growth. César Ritz Colleges, $\mathrm{CH}-$ 3900 Brig, Switzerland.

RHODUS, T., SWARTZ, J. \& HOSKINS, J. 1994. Ohio consumer opinions of roadside markets and farmers' markets. Report to the Ohio Rural Rehabilitation Program. Ohio: Department of Agriculture [Online]. Available from: www.hcs.ohiostate.edu/hcs/EM/rfmarket/rfmarket.html [Accessed: 06/01/2013].

SA-VENUES. S.a. South Africa attractions [Online]. Available from: www.sa-venues.com [Accessed: 03/12/2011].

SCIALABBA, N. 2000. Factors influencing organic agriculture policies with a focus on developing countries. (Paper read at the $13^{\text {th }}$ IFOAM 2000 Scientific Conference, 28 August, Basel, Switzerland). Unpublished.

SONMEZ, S.F. \& GRAEFE, A.R. 1998. Influence of terrorism, risk on foreign tourism decisions. Annals of Tourism Research, 25:112-144.

SOUTH AFRICA. Department of Agriculture, Forestry and Fisheries. Directorate: Economic Research Division. 2010. The declining contribution of agriculture to GDP: is the role of agriculture becoming less important? [Online]. Available from: http://www.daff.gov.za/docs/Economic analysis/DecliningContributionOfAgricToG DP.doc. [Accessed: 10/01/2013]

SOUTH AFRICA. Department of Environmental Affairs and Tourism (DEAT). 1996. White paper on the Development and Promotion of Tourism in South Africa. Pretoria: Government Printer.

SOUTH AFRICA. Department of Environmental Affairs and Tourism (DEAT). 2005. 2010 Soccer World Cup Tourism Organisation Plan Executive Summary. Pretoria: South African Tourism.

TIFFLIN, W. 2005. Agritourism in KwaZulu-Natal. Tourism KwaZulu-Natal Occasional paper No.35:1-6.

VAUPEL, S. 1985. Direct marketing in California. California Agriculture, Sept.-Oct.

VILJOEN, J. \& TLABELA, K. 2006. Rural tourism development in South Africa: trends and challenges. Cape Town: HSRC Press.

WASHINGTON STATE DEPARTMENT OF AGRICULTURE. 2010. Selling directly to consumers: direct marketing strategies. Small Farm and Direct Marketing Handbook, 2:1-4.

WEAVER, D.B. \& FENNELL, D.A. 1997. The vacation farm sector in Saskatchewan: a profile of operations. Tourism Management, 18(6):357-365. 
WILliAMS, P., PARIDAEN, M., DOSSA, K. \& DUMAIS, M. 2001. Agritourism market and tourism development status report: Centre for Tourism Policy and Research. Burnaby, Canada: Simon Fraser University.

WORLD TRAVEL AND TOURISM COUNCIL. 2002. South Africa: the impact of travel and tourism on jobs and the economy. London: World Travel and Tourism Council. 